Review

\title{
Forage Options for Dairy Farms with Reduced Water Availability in the Southern Murray Darling Basin of Australia
}

\author{
Mary-Jane Rogers *, Alister Lawson and Kevin Kelly \\ Agriculture Victoria, Department of Economic Development, Jobs Transport and Resources, Private Bag, \\ 255 Ferguson Rd., Tatura, VIC 3616, Australia; alister.lawson@ecodev.vic.gov.au (A.L.); \\ kevin.kelly@ecodev.vic.gov.au (K.K.) \\ * Correspondence: maryjane.rogers@ecodev.vic.gov.au
}

Received: 26 October 2017; Accepted: 12 December 2017; Published: 18 December 2017

\begin{abstract}
The dairy industry in the southern Murray Darling Basin region of Australia is a major consumer of irrigation water because rainfall is low relative to evapotranspiration and the industrys relies heavily on irrigated temperate pastures and fodder crops. Water reforms, and potential climate change scenarios for this region suggest that there will be an overall decline in rainfall and water available for irrigation in the future. For the irrigated dairy industry to remain economically viable, there is a need for dairy farmers to improve the water productivity (WP) of their forage systems and to be able to respond to year-to-year, and within year, variation in water availability. Researchers and dairy farmers are evaluating strategies to increase WP. These include: (i) selecting better-adapted species for current and predicted climatic conditions; (ii) using species that can survive and still be productive under reduced irrigation and then recover when full irrigation is restored; (iii) modifying irrigation strategies to reduce water use whilst maintaining WP; and (iv) grazing management strategies that facilitate the survival during, and recovery after, periods of moisture stress. This review will examine these strategies and discusses their potential to optimise forage production from irrigation water inputs so that the dairy industry in the southern Murray Darling Basin remains viable in the future.
\end{abstract}

Keywords: dairy production; deficit irrigation; irrigated pastures; water productivity; water use

\section{Introduction}

The Murray Darling Basin of south-eastern Australia covers an area of over 1 million $\mathrm{km}^{2}$. Approximately 12,000 $\mathrm{km}^{2}$ (or 1\%) of the Basin was irrigated in 2015/2016, which represents around $60 \%$ of the total area that is irrigated for agricultural production in Australia [1] (Figure 1). The irrigated area in the Basin supports perennial and annual horticulture, summer and winter cropping, and grazing industries [1]. In the southern part of the Murray Darling Basin (northern Victoria/Southern New South Wales-"the region"), dairy production based on irrigated forages is a major industry and accounts for about $20-25 \%$ of Australia's total milk production [2].

The region where the dairy industry is mainly located receives 300 to $550 \mathrm{~mm} /$ year of rainfall on average, and has potential evapotranspiration $\left(\mathrm{ET}_{0}\right)$ of 1100 to $1350 \mathrm{~mm} /$ year. Pasture and fodder crops for the dairy industry are irrigated through the spring, summer and autumn periods when temperatures and radiation inputs are conducive to high rates of plant growth. As a dairy region, the southern Basin is unique throughout the world because of its low rainfall, high summer temperatures and reliance on irrigated pastures. The average monthly temperatures in summer (January/February) range between minima of $14-16{ }^{\circ} \mathrm{C}$ and maxima of $30-32{ }^{\circ} \mathrm{C}$, while in winter (July/August) they range from a minimum of $3-4{ }^{\circ} \mathrm{C}$ to a maximum of $14-15^{\circ} \mathrm{C}$ [4]. Soils of the region 
are principally red-brown earths [5], chromosol or sodosols [6]. The prolonged Millennium Drought which occurred from 1997 to 2009 saw major reductions in rainfall across south-eastern Australia and record low inflows into storages. In this region, a drought is defined as a prolonged, abnormal dry period when the amount of available water is insufficient to meet normal use [7].

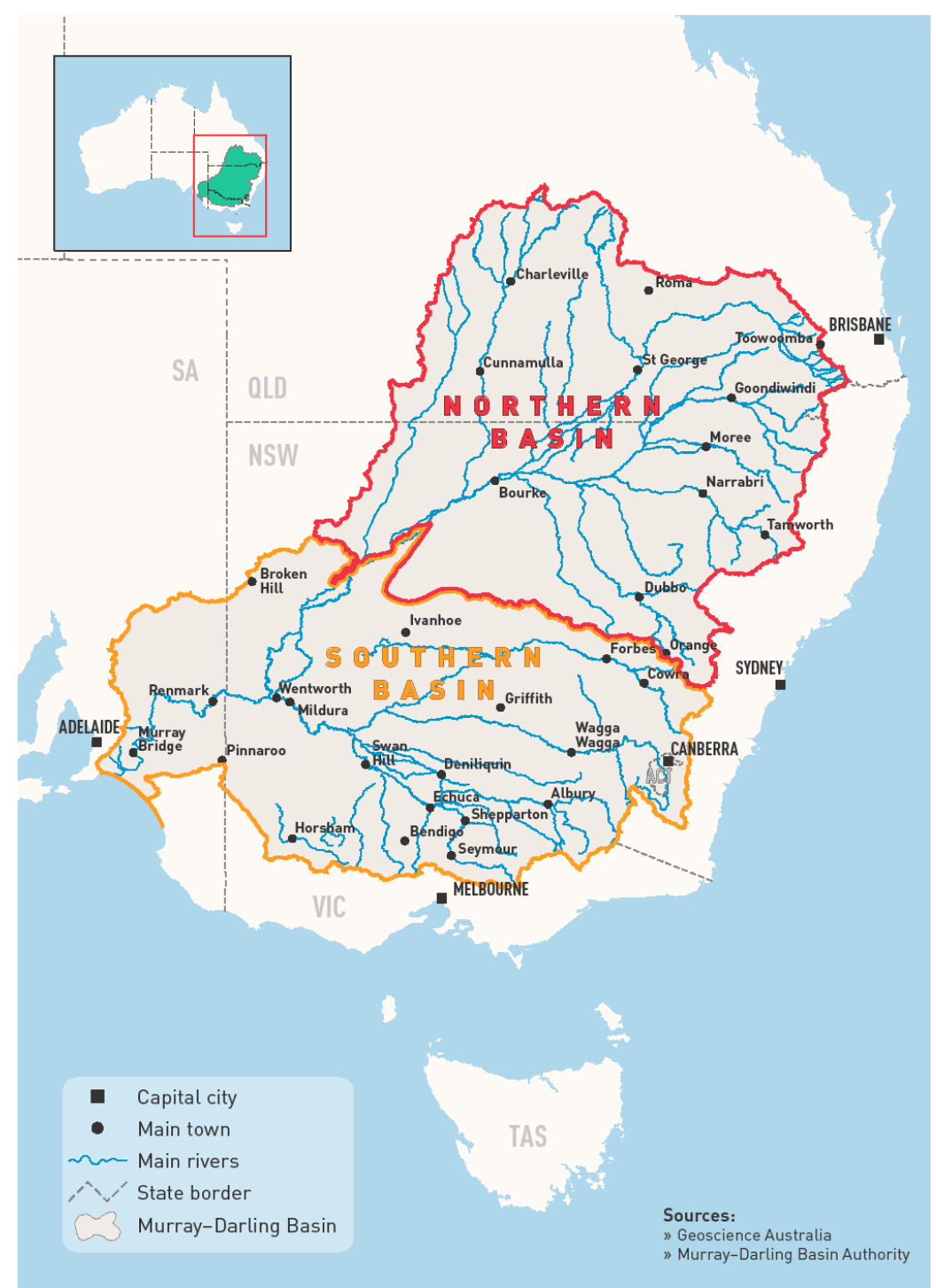

Figure 1. Map of the Murray Darling Basin in eastern Australia, showing the location of both the northern and southern Basin [3].

The Murray Darling Basin Plan, which came into effect in 2012 [8], has led to a reduction in the amount of water available for irrigation regionally, and has increased flexibility in water trading, either temporarily or permanently, between areas and industries within the southern part of the Basin. When coupled with regional climate change predictions of less rainfall, higher temperatures and higher potential evapotranspiration [9]; in the future, less water is likely to be available for irrigation while individual crop demand may increase. By 2050, and under a medium climate change scenario, the likelihood that irrigation farmers in northern Victoria receive a full water allocation in any year is predicted to be lower (by at least 10\%) than the current base of $90-100 \%$ of years, and zero irrigation water allocations are likely to occur in $1-3 \%$ of years [10].

While all agricultural industries in the region have production challenges with climate, water availability and commodity prices, the dairy industry is particularly vulnerable because feed represents 
a high proportion of total farm costs and because of its high reliance on home-grown forages. Overall, dairy farmers in the region are being forced to use water more productively and efficiently [11,12], and to select forage species that can persist, be productive, and provide feed with suitable nutritive characteristics for animals in situations where water availability is lower. In this review, we have focused on irrigated forage systems which support the dairy industry in the southern Murray Darling Basin.

Irrigated forage systems for the dairy industry are based on pastures that are generally border-check irrigated, where water is flooded over a graded irrigation bay $[13,14]$. This irrigation method suits the clay, and clay loam soils of the region because there is minimal loss of water below the rootzone to groundwater, particularly when underlying water tables are high (1-2 $\mathrm{m})$ [15].

Perennial pastures irrigated by the border-check method have an irrigation water requirement that varies widely depending on rainfall and evapotranspiration but is typically between 7 and $10 \mathrm{ML} /$ ha.year [16,17], whereas annual forages typically require 2-6 ML/ha.year [17-19] (Figure 2). The amount of irrigation water available to a landholder in any given year depends on the volume of water in regional storage available for irrigation, the landholders' share of regulated water, and the availability and price of traded irrigation water. These factors impact farm management practices and determine irrigation strategies (such as when to use irrigation water), forage selection (what species to grow), and the grazing/management strategies applied to forages.

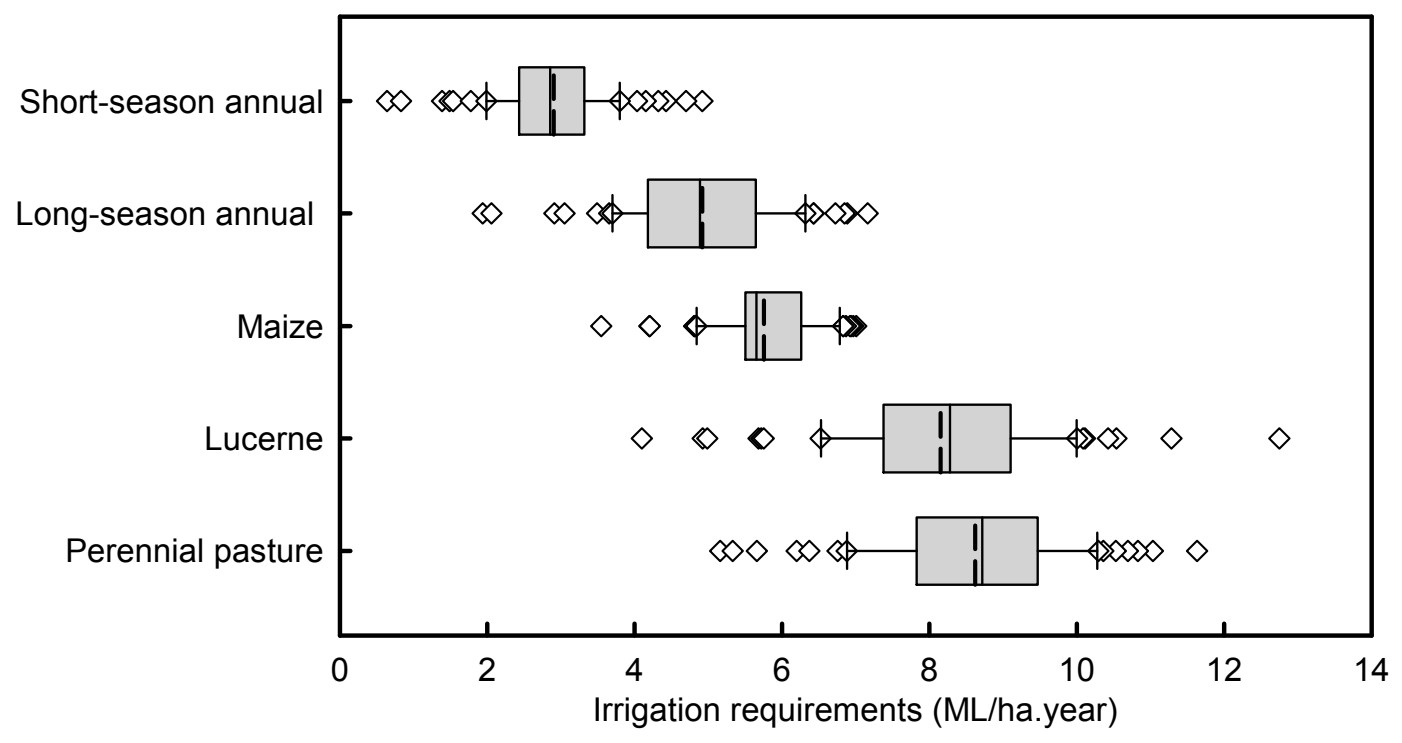

Figure 2. Estimated irrigation water-use of five forage types at Kyabram for 1935-2005. The short-season annual pastures are subterranean clover/short-lived ryegrass; the long-season annual pastures are Persian clover/short-lived ryegrass; and the perennial pastures are perennial ryegrass/white clover. The boxes indicate the 25,50 and 75 percentile bands, the whiskers the 10 and 90 percentile bands, and the circles the top or bottom $10 \%$ of individual data points. The thick dashed line denotes the mean value (redrawn from [17]).

A survey of irrigated dairy farms in the region conducted about 20 years ago [20] found that there was a large range of water use efficiencies (WUE) (Table 1) between farms (25-115 kg milk fat plus protein/ML water). This suggested that there was scope for many farms to increase efficiency and productivity by modifying farm management practices depending on the input variables. However, later studies found no relationship between a reduction in irrigation water allocations and an increase in WUE [21] and no simple, direct association between WUE and profitability [22].

Total Water Productivity (TWP) (see Table 1) is a useful way of comparing the efficiency of different irrigation management and forage systems in the region [23]. This is because under conditions where water is scarce, measurements of production per unit of water may be more important to the farmer 
than an emphasis on production per unit area [24]. Thus, comparative data on the TWP of different forages can be valuable to farmers so that forage production is optimised under conditions of limited water availability and increasing water costs [23] (see Table 2).

Table 1. Definitions and units of keys terms used in the review.

\begin{tabular}{|c|c|c|c|}
\hline Term & Abbreviation & Units & Definition \\
\hline Evaporation less rainfall & E-R & $\mathrm{mm}$ & $\begin{array}{l}\text { Cumulative Class A Pan evaporation less } \\
\text { rainfall since the last irrigation or runoff } \\
\text { event. In many cases a pan factor, often } 0.8 \text {, } \\
\text { is used to modify pan evaporation [25]. } \\
\text { This method has been superseded by the } \\
\text { ETo-R method. }\end{array}$ \\
\hline Evapotranspiration less rainfall & ETo-R & $\mathrm{mm}$ & $\begin{array}{l}\text { Cumulative potential evapotranspiration less } \\
\text { rainfall since the last irrigation or runoff } \\
\text { event. ETo is calculated using the FAO } 56 \\
\text { methodology [26]. This method supersedes } \\
\text { the E-R method. }\end{array}$ \\
\hline Full irrigation & & & $\begin{array}{l}\text { The application of irrigation water at } \\
\text { an amount to meet full crop } \\
\text { requirements [24]. }\end{array}$ \\
\hline Deficit irrigation & & & $\begin{array}{l}\text { The application of irrigation water at an } \\
\text { amount below full crop requirements [24]. } \\
\text { The terms restricted and limited irrigation } \\
\text { may also be used. }\end{array}$ \\
\hline Water use efficiency & WUE & kg MS/ML & $\begin{array}{l}\text { The amount of milk produced (measured in } \\
\mathrm{kg} \text { milk solids (MS)) from pasture per } \\
\text { megalitre of water applied by irrigation plus } \\
\text { effective rainfall [20] }\end{array}$ \\
\hline Water productivity & WP & $\begin{array}{l}\mathrm{kg} \mathrm{DM} / \mathrm{ha} \cdot \mathrm{mm} \\
\text { or t DM/ML }\end{array}$ & $\begin{array}{l}\text { The annual amount of forage biomass } \\
\text { removed divided by the annual total water } \\
\text { input [27] }\end{array}$ \\
\hline Irrigation water productivity & IWP & as above & $\begin{array}{l}\text { Same as per WP except that only the } \\
\text { irrigation water is included [23] }\end{array}$ \\
\hline Marginal water productivity & MWP & as above & $\begin{array}{l}\text { Same as WP except that both biomass and } \\
\text { water refer to the marginal amounts as } \\
\text { a result of irrigation, or an increased level of } \\
\text { irrigation [23] }\end{array}$ \\
\hline Total water productivity & TWP & as above & $\begin{array}{l}\text { Same as per WP except that the water input } \\
\text { includes irrigation, rainfall and changes in } \\
\text { soil moisture [23] }\end{array}$ \\
\hline
\end{tabular}

Table 2. Irrigation water productivity (IWP) and total water productivity (TWP) (see Table 1) for forage removal (kg DM/ha.mm) for six forage systems (2005 and 2006) [23].

\begin{tabular}{cccccccc}
\hline Year & PRG/WC & Fes/WC & Lucerne & DCrop & PC/IRG & SC/IRG & 1.s.d. $(\boldsymbol{p}=\mathbf{0 . 0 5})$ \\
\hline \multicolumn{7}{c}{} & \multicolumn{7}{c}{ IWP } & & \\
\hline 2005 & 20.7 & 21.3 & 26.6 & 24.9 & 36.2 & 30.4 & 3.5 \\
\hline 2006 & 12.3 & 14.2 & 18.6 & 15.9 & 17.4 & 21.3 & 2.4 \\
\hline 2005 & 13.3 & 13.6 & 14.2 & 15.5 & 17.2 & 11.9 & 1.4 \\
2006 & 10.5 & 12.0 & 15.4 & 13.2 & 13.0 & 12.9 & 1.3 \\
\hline
\end{tabular}

Forage systems are: PRG/WC, perennial grass/white clover; Fes/WC, tall fescue/white clover; DCrop, double crop-oats from late March to late October and millet from early November to mid-March; PC/IRG, Persian clover/Italian ryegrass-first irrigation in mid-February and last irrigation in late November; SC/IRG, subterranean clover/Italian ryegrass-first irrigation in mid-March and last irrigation in late October.

Over the last two decades, the on-farm feed production systems, based primarily on annual and perennial pastures [13], have changed substantially. These changes are the collective result of; 
reduced water availability-due to changes in Government water policy, the transfer of water between industries and a series of drought years-and on-farm changes such as larger herd sizes, higher per cow production and increased supplement use, which reduce the proportion of grazed pasture in the cows' diet. These changes are likely to continue into the future as dairy farming systems adapt to ongoing water availability issues, and technology and management changes.

This review outlines strategies that may be required to optimise forage production from all water inputs so that the dairy industry in the southern Murray Darling Basin remains viable into the future. The focus is on forages for the dairy industry and not on optimising efficiencies in using conserved fodder and other "feed" on farms. Issues related to sustainability of irrigation systems in the region such as drainage, water tables and salinity are not addressed in this review.

\section{Strategies to Improve Productivity with Limited Water}

\subsection{Species Performance under Full Irrigation}

The main dairy forage systems in the southern Murray Darling Basin region are perennial pastures and winter active annual pastures, with smaller areas of lucerne (Medicago sativa L.), winter fodder crops such as winter cereals, and summer fodder crops. Perennial pastures require a year-round supply of water to meet plant growth requirements [14] while annual pastures are irrigated from March/April to October/November. The area of each of these forages varies from year to year depending on the season, the availability and cost of water, the potential value of that forage, the suitability of the forage to the farm system and other economic factors such as the cost of supplements and the milk price.

\subsubsection{Perennial Forages}

Irrigated perennial pastures were the dominant forage system for the dairy industry in the region and occupied around three-quarters of the milking area on most farms until the late 1990s [13,14]. However, since then, the proportion of perennial pastures has declined and the area of annual pastures and other forage crops has increased as a response of climate and water reforms leading to a series of years with lower water allocations [28]. Perennial pastures are based on perennial ryegrass (Lolium perenne L.) and white clover (Trifolium repens L.), although red clover (T. pratense L.) and strawberry clover (T. fragiferum L.), are also sown. Paspalum (Paspalum dilatatum Poir.) is rarely sown but often invades perennial ryegrass/white clover pastures and eventually dominates them over summer [29]; production from paspalum and other C4 grasses ceases during the cooler months of May to September.

Perennial ryegrass is the preferred perennial grass species in the region because of its rapid establishment, strong seedling vigour, superior nutritive characteristics and well-understood grazing management [12]. While tall fescue (Festuca arundinacea (Schreb) Darbysh.) is an important component of perennial pastures in many parts of the world [30] and is believed to be well-suited to the environment of the southern Murray Darling Basin [31], its uptake by dairy farmers in the region has been low and limited by issues such as slow establishment and lack of confidence and knowledge regarding grazing management [31]. White clover is the preferred perennial legume species because of its superior nutritive characteristics and compatibility with perennial grasses in grazed systems. The area sown to lucerne in the region is increasing and it is generally grown as a pure stand for grazing and/or fodder conservation.

Generally, white clover and perennial ryegrass pastures have a competitive advantage in irrigated areas compared to annual pastures because of the potential for year-round feed production [27]. Perennial pastures produce between 14 and $20 \mathrm{t} \mathrm{DM} /$ ha.year under full irrigation [32]. Pure swards of white clover may produce up to $14 \mathrm{t} \mathrm{DM}$ /ha.year under frequent irrigation [33] while pure swards of red clover may produce a similar amount but usually last for less than two years [33] (Table 3). Lucerne swards can produce up to $23 \mathrm{t} \mathrm{DM} /$ ha.year [33]. 
Table 3. The effect of species and irrigation interval on harvested dry matter yield ( $\mathrm{DM} / \mathrm{ha}$ ), separated into irrigated (August to May) and rain-fed (May to August) periods [33].

\begin{tabular}{|c|c|c|c|c|c|c|c|}
\hline \multirow{2}{*}{$\begin{array}{c}\text { Irrigation Treatment } \\
\text { (E-R) }\end{array}$} & \multicolumn{2}{|c|}{$\begin{array}{c}\text { December } 1987 \text { to } \\
\text { August } 1988\end{array}$} & \multicolumn{2}{|c|}{$\begin{array}{l}\text { August } 1988 \text { to } \\
\text { August } 1989\end{array}$} & \multicolumn{2}{|c|}{$\begin{array}{l}\text { August } 1989 \text { to } \\
\text { August } 1990\end{array}$} & \multirow{2}{*}{$\begin{array}{c}\begin{array}{c}\text { August to } \\
\text { December } 1990\end{array} \\
\text { Irrigation } \\
\end{array}$} \\
\hline & Irrigation & Rain-Fed & Irrigation & Rain-Fed & Irrigation & Rain-Fed & \\
\hline \multicolumn{8}{|c|}{ White clover (cv. Haifa) } \\
\hline $40 \mathrm{~mm}$ & 10.9 & 4.4 & 11.0 & 3.5 & 11.6 & 2.4 & 5.0 \\
\hline $80 \mathrm{~mm}$ & 8.9 & 4.7 & 9. & 3.5 & 7.8 & 2.4 & 3.0 \\
\hline $120 \mathrm{~mm}$ & 6.3 & 4.7 & 8.4 & 3.8 & 5.8 & 2.5 & 2.3 \\
\hline \multicolumn{8}{|c|}{ Red clover (cv. Redquin) } \\
\hline $40 \mathrm{~mm}$ & 10.9 & 2.3 & 13.6 & - & - & - & - \\
\hline $80 \mathrm{~mm}$ & 10.0 & 2.0 & 13.0 & - & - & - & - \\
\hline $120 \mathrm{~mm}$ & 7.9 & 2.1 & 10.8 & - & - & - & - \\
\hline \multicolumn{8}{|c|}{ Lucerne (cv. Validor) } \\
\hline $40 \mathrm{~mm}$ & 7.7 & 1.4 & 19.2 & 1.2 & 21.4 & 1.2 & 9.2 \\
\hline $80 \mathrm{~mm}$ & 7.1 & 1.4 & 19.9 & 1.5 & 21.2 & 1.4 & 8.5 \\
\hline $120 \mathrm{~mm}$ & 6.9 & 1.8 & 19.3 & 1.4 & 20.9 & 1.3 & 8.7 \\
\hline \multicolumn{8}{|c|}{ l.s.d. $(p=0.05)$} \\
\hline Irrigation main effect & - & n.s. & - & n.s. & - & n.s. & - \\
\hline Species main effect & - & -0.34 & - & 0.47 & - & 0.24 & - \\
\hline Interaction & 1.25 & - & 1.05 & - & 1.95 & - & 0.77 \\
\hline
\end{tabular}

\subsubsection{Annual Pastures}

Irrigated annual pastures are generally based on Italian ryegrass (L. multiflorum L.) and either subterranean (T. subterraneum L.) or Persian (T. resupinatum L.) clovers, but other annual legume species such as balansa (T. michelianum Savi) or berseem (T. alexandrinum L.) clovers are also grown. Annual pastures range from pure ryegrass, to mixed ryegrass/legume, to pure legume swards. Dry matter production from annual pastures ranges from 8 to $15 \mathrm{t} \mathrm{DM} /$ ha.year [32,34,35]. In general, during autumn and winter, these annual pastures produce more dry matter than perennial pastures [17]. However, these annual species flower, set seed and senesce in late spring/early summer and some require re-establishment in autumn. Subterranean clover is generally the preferred annual clover because of its ability to regenerate annually [18]. The Persian clover genotype grown in the region is a long-season type and grows for longer in spring than other annual legumes [36]. Irrigating annual pastures in autumn and spring allows for an extended and more reliable growing season compared to rain-fed pastures and provides some management flexibility [36]. Balansa clover has not been widely adopted in the region and is usually only grown if conditions are too saline or waterlogged for subterranean clover [37].

\subsubsection{Winter Fodder Crops}

Dual-purpose winter cereals such as wheat (Triticum aestivum L.), barley (Hordeum vulgare L.) and oats (Avena sativa L.) are the major winter fodder crops grown in the region. These cereals may be grown either non-irrigated, or with a limited number of irrigations in the autumn and/or spring. Cereals are generally grazed several times in autumn/winter prior to excluding livestock in spring for fodder conservation, or, more infrequently, harvested for grain. Dry matter production from grazed cereals over the autumn/winter period averages $3.0 \mathrm{t} \mathrm{DM} /$ ha, with a further $7.0 \mathrm{tDM} /$ ha produced at a single conservation cut [17]. Dry matter yields vary with rainfall and the amount of irrigation water used.

\subsubsection{Summer Fodder Crops}

Summer fodder crops grown in the region include maize (Zea mays L.), millet (Echinochloa utilis Ohwi \& Yabuno) and sorghum (Sorghum spp.). Yields of maize grown for silage under four soil 
management systems and two irrigation methods (surface and drip) over summer (November to March/April-125 days) have ranged from 18 to $28 \mathrm{t}$ DM/ha [38]. Maize silage yields on commercial farms have ranged from $19 \mathrm{t} \mathrm{DM} /$ ha when grown under flood irrigation to $21 \mathrm{t} \mathrm{DM} / \mathrm{ha}$ when grown under centre pivot irrigation [19]. Forage sorghum crops have produced yields ranging from 14 to $19 \mathrm{t} \mathrm{DM} /$ ha when cut three times, to 20-31 t DM/ha when cut once, with dry matter digestibility (DMD) being higher for the multiple cut than for the single cut crops (60-65\% vs. 53\% DMD) [39]. Yields of millet have ranged from 8-9 t DM/ha when double cropped with oats [17], to 12-18 t DM/ha when sown as the sole crop for the growing season [39].

The dairy industry in the region has a range of species options, all of which have their advantages and limitations. If the climate warms as predicted, more tropical species including legumes may have a greater role, while the use of temperate perennials is likely to decline. As water availability reduces, and the cost of irrigation water increases, there is a need to grow forage types with higher WP. However, these forages are often more expensive to grow and usually involve conservation instead of direct grazing, which may necessitate additional on-farm capital investment. With the year to year variation in water availability and price, the on-farm forage systems are in a constant state of change with no standard optimal solution. Consequently, forage systems may vary from year to year in response to environmental and economic circumstances. The ability to retain some degree of flexibility is therefore an important consideration in forage selection.

\subsection{Species Performance under Limited Irrigation}

\subsubsection{Perennial Forages}

When water is limited, the ability of plants to survive, persist and/or be productive is determined by many factors including genotype, phenotypic plasticity, osmotic adjustment, the prolonged maintenance of positive turgor and rooting depth [40]. Generally, perennial forage and crop species are better-suited to growing under drought conditions or deficit/restricted irrigation (see definition in Table 1) because their deeper root system allows them to access stored soil water from greater depths and in greater amounts compared with annual species [41,42].

White clover, the preferred legume species in perennial pastures, is recognised as being sensitive to water stress [43] and needs to be irrigated frequently to maintain productivity [33,43]. In a study comparing the WP, production and water use of three perennial forage legumes (white clover, red clover and lucerne), at three different irrigation intervals, Kelly et al. [33] showed white clover to be more sensitive to variations in irrigation frequency than either red clover or lucerne. This was attributed to its relatively shallow root structure and density with most of its roots located in the top $20 \mathrm{~cm}$ of the soil profile [44-46] and therefore its inability to access soil water stored at depth. White clover was also shown to be the least tolerant to deficit irrigation of 15 forage species evaluated in a humid subtropical climate at Camden, NSW, which again was attributed to its root architecture and density [12,47].

Red clover is a deep-rooted species that can use soil moisture at depth [33,48]. However, despite red clover being more tolerant of longer irrigation intervals than white clover, its performance in northern Victoria has been poor, with pure swards not surviving through the second year, regardless of irrigation management [33]. Similarly, Skinner et al. [49] found that red clover had limited persistence when grown under rainout shelters in Pennsylvania, northeast USA over two seasons. Red clover may perform better in a humid subtropical climate [12] with reported dry matter yields under limited and non-limiting irrigation in this climate being higher than those for both lucerne and white clover, particularly in the first two years of the study. Thus, it would seem that red clover may need to be re-sown on a regular basis to ensure sward productivity in the southern Murray Darling Basin.

Lucerne is known to possess a degree of drought tolerance and to have a wide adaptation range [33,50]. This species is generally suited to lighter soils and consequently, has not been an important component of the dairy feedbase on the heavier clay soils in southern Australia [51]. However, the area sown to lucerne in the southern Murray Darling Basin is expanding due to a reduced 
risk of stand damage from waterlogging because of a combination of improvements in irrigation management, weather forecasting, disease resistance and an increase in the depth of regional water tables because of a series of dry winters. There have also been improved perceptions of lucerne's value relating to its productivity, nutritive characteristics and its ability to fill summer feed gaps, as well as an appreciation of its ability to survive dry conditions and then respond to rainfall and irrigation [52-54].

The irrigation management of lucerne can be more flexible compared with other forage species. For example, Kelly et al. [33] showed that lucerne had greater WP and maintained dry matter production over a wider range of irrigation intervals than either white or red clover. Similarly, Neal et al. [12] found that lucerne was the most tolerant to deficit irrigation of the 15 perennial forage species that they evaluated. This tolerance to low water application has been related to its deep root system that allows lucerne to access water deep in the soil profile [55]. Under frequent irrigation on a red-brown earth, water extraction by lucerne is largely confined to the upper $0.5 \mathrm{~m}$ of the profile. However, when lucerne is exposed to moisture stress, it is able to extract water from progressively greater depths after the onset of stress symptoms during the day, and after water use has already been affected by soil moisture deficits $[33,56]$.

Recent research on the effects of limiting and non-limiting irrigation management on water use, dry matter production, and persistence of lucerne over five irrigation seasons showed that dry matter production was directly related to total water use [54] (see Figure 3). The resilience of lucerne was also demonstrated as it was able to fully recover once full irrigation was resumed [54], thereby indicating its suitability for situations when the water supply is limited and variable. Lucerne is also able to minimise water usage during water stress by reducing its metabolism, becoming semi-dormant and by its high stomatal resistance to water loss in the leaves [57].

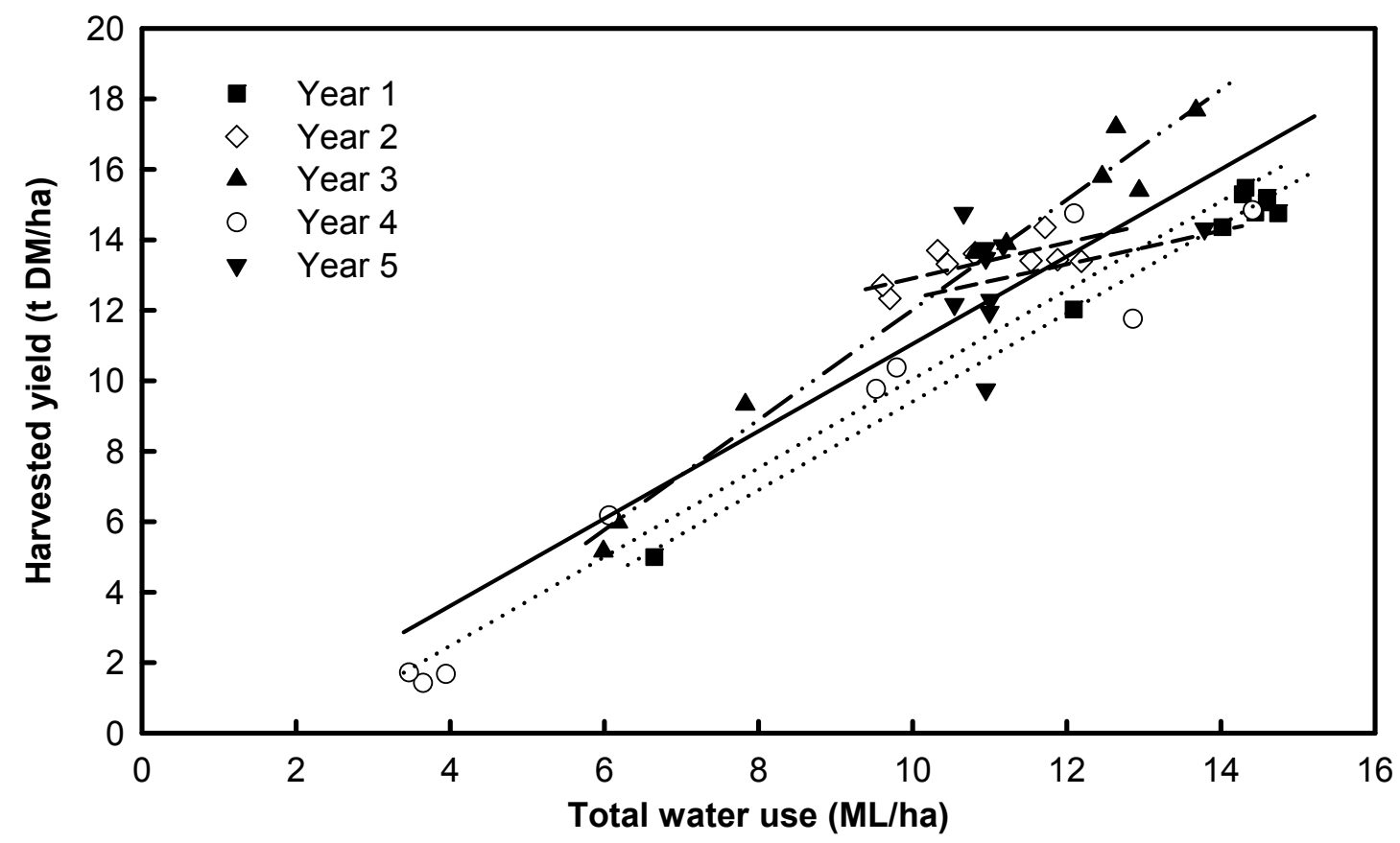

Figure 3. Relationships of dry matter production to total water use for lucerne grown under a range of irrigation treatments over five years. Total water use includes irrigation inputs, effective rainfall (rainfall less any runoff from rain) and change in soil water content ( $0-2.5 \mathrm{~m}$ depth). The solid line is a single regression line for the five years while the dotted/dashed lines are individual regression lines for each of the five years [54].

Other perennial forage legumes and herbs such as Talish clover (T. tumens Steven ex M. Bieb), chicory (Cichorium intybus L.) and plantain (Plantago lanceolata L.) may offer potential over summer dry 
conditions because their deep tap root allows them to access water at depth [49,58]; however, there has been some concern about their long-term persistence [12]. These species may also be worth evaluating under restricted irrigation conditions and may perform better than red clover.

Perennial ryegrass requires relatively large amounts of water to sustain growth [59] and is best-suited to regions where summer temperatures are mild to moderate, as net photosynthetic rates of perennial ryegrass decline as temperatures increase above $20^{\circ} \mathrm{C}$ [60]. Consequently, perennial ryegrass's performance over summer can be limited because of a combination of high water demand and high temperatures [61] which affect dry matter production [62], plant density and persistence [63]. Studies comparing the performance of perennial ryegrass accessions during drought exposure and rehydration show that significant variations in traits such as dry matter production, early vigour, leaf wilting, leaf water content, canopy temperature and chlorophyll fluorescence could be related to a few genes $[64,65]$. Perennial ryegrass cultivars with a northwest Spanish background are suggested to have an improved tolerance to summer moisture deficit and may adopt a drought survival strategy compared with cultivars with a more European background [66].

Tall fescue has been identified as an alternative to perennial ryegrass in dairy pastures because of its higher production through summer and similar nutritive value under appropriate management strategies [31]. In a glasshouse study evaluating the morphological and physiological responses of three grasses (perennial ryegrass, cocksfoot and tall fescue) to varied moisture availability, Turner et al. [67] concluded that tall fescue appeared to have the greatest scope for persistence under moisture stress because its dry matter was less affected and it was able to recover more quickly following re-watering. Tall fescue accessions also differ with regard to tolerance of summer drought $[68,69]$ suggesting that there may be opportunities to select and grow more adapted varieties under moisture stress conditions.

Phalaris (Phalaris aquatica L.) is another temperate perennial grasses species that has deep roots and is generally more tolerant to drier conditions than perennial ryegrass. However, phalaris is not grown in dairy pastures in the region because it nutritive value is generally lower than perennial ryegrass [52] and many cultivars have low growth rates over summer.

Temperate perennial grasses have a range of strategies to help survive the impacts of drought including dehydration avoidance, dehydration tolerance and summer dormancy [70]. In seeking to understand these different strategies so that management options to mitigate the effects of drought can be employed, it is important to distinguish between the way that mature and meristematic tissues respond to increasing levels of drought [71] and the way that plants respond to moderate, compared to severe, water stress [72].

Plants using dehydration avoidance seek to maintain a high tissue water potential during periods of water stress, largely through the early onset of leaf senescence. With dehydration tolerance, plant water potential is reduced as moisture stress increases, enabling growth to continue for longer than plants that are dehydration avoiders. Plants with dehydration tolerance also maintain the integrity of cell membranes under moisture stress. Both dehydration tolerance and dehydration avoidance approaches are often associated with an extensive root system [70]. Summer dormancy is an important trait that could improve the persistence of temperate perennial grasses in environments with long, dry summers $[41,68]$. Most of the research on summer dormancy in perennial grasses has been undertaken on cocksfoot, tall fescue and phalaris, with information on perennial ryegrass being more limited.

Summer dormancy is expressed under increasing photoperiod and temperature and involves cessation of leaf growth, senescence of foliage and dehydration of leaf meristems [71]. Summer dormant plants avoid summer drought stress by not growing or reproducing during summer, as both of these processes are severely affected by unfavourable environmental conditions [73]. Selection of genotypes with summer dormancy would be beneficial for systems where deficit/restricted irrigation is inevitable. However, plant drought tolerance is a complex quantitative trait involving multiple metabolic pathways [64] with a number of genes involved [74]. 
Tropical or subtropical C4 grasses such as paspalum and kikuyu (Pennisetum clandestinum Hochst. Ex Chiov), have greater tolerances to high temperatures than temperate $C 3$ grasses [29,61]. For example, paspalum can maintain its canopy conductance up to an E-R deficit (see Table 1) of $80 \mathrm{~mm}$ without affecting photosynthesis [61] compared to an E-R deficit of 35-50 $\mathrm{mm}$ for white clover and perennial ryegrass. Research by Neal et al. [12,47] under a climate that is less extreme than that of the southern Murray Darling Basin, showed that kikuyu produced significantly higher dry matter yields and had higher WP under extreme deficit irrigation than 15 other perennial forages that were evaluated, although the yield did decline significantly in Year 3. However, paspalum and kikuyu have nil, or very limited, cool season production, and lower nutritive values than temperate $\mathrm{C} 3$ grasses such as perennial ryegrass or tall fescue, which can limit milk production [75].

\subsubsection{Annual Pastures}

Irrigation is only used on annual pastures in autumn and spring to increase the length and reliability of the early and late season growth to provide some management flexibility [36]. Consequently, their performance under restricted irrigation over summer is not relevant. Under conditions of limited irrigation water availability, farmers may be able to grow more forage using winter-growing annual systems than perennial systems, however, this may not take into account other factors such as the seasonality of feed supply, nutritive characteristics and the economic costs of production and conservation [12].

\subsubsection{Winter Fodder Crops}

Winter cereals are often sown in preference to annual pastures when water availability is low as they can access soil moisture from deeper in the profile and they are able to survive and grow better when soil moisture is limited. Winter cereals can be sown either dry or with a single, or several, irrigations and then rely upon either winter rainfall or soil moisture for their autumn/winter growth. Winter cereals are rarely sown in preference to annual pastures in situations where there is sufficient irrigation water to fully irrigate due to the similar dry matter production and better nutritive characteristics of the annual pastures [12].

\subsubsection{Summer Fodder Crops}

Summer fodder crops require irrigation water to achieve acceptable dry matter yields, due to the low and unreliable summer rainfall of the region. However, there has been few studies undertaken in the region on how to grow summer fodder crops with limited irrigation water. One of the key considerations with growing a summer fodder crop is to ensure that whatever water is applied will result in a worthwhile harvested yield. For example, if, at the start of the irrigation season, it is anticipated that there will be limited water available, one option is to grow a forage that can be grazed multiple times, such as millet or sorghum [39]. In this situation if the irrigation season has to be cut short due to lack of water, the farmer has already received a worthwhile return on the water invested. In contrast, when maize is grown for silage in water-limited situations, farmers may only grow a small area of crop to ensure that there is enough water to irrigate for long enough to achieve a high grain content and optimal nutritive characteristics of the silage [76].

Ideally, the most suitable species for deficit irrigation conditions may be ones that combine drought resistance with some ability to respond to irrigation. Alternatively, annual species may be grown that may require renovation or resowing each year to maintain productivity. Under typical production costs when irrigation water is plentiful, perennial pastures provide a cheaper, and easily managed, feed source compared to annual pasture or fodder crop systems [77]. However, under conditions of limited irrigation water availability and high water prices, a greater proportion of annual pastures or fodder crops should be grown which will increase WP [9] and minimise the economic impact of reduced water allocations [77]. 


\section{Irrigation Strategies to Improve Water Productivity}

The modification of irrigation strategies to use less water, minimise productivity loss and maintain plant survival may be another way to optimise the total water productivity of dairy pastures when water is limited. Deficit irrigation (Table 1), can be a deliberate irrigation strategy chosen because of restrictions in the amount of water available for irrigation, and therefore it can be an important tool to reduce irrigation water use [24]. However, deficit irrigation can be difficult to implement in dairy situations where the goal is the optimum production of biomass due to the close relationship between water use and biomass production $[24,54]$. Deficit irrigation strategies that can be applied by farmers include irrigating for just part of the season, reducing the amount of water applied at each irrigation during the season, or not irrigating for an entire summer season. Most of the research on deficit irrigation strategies has been conducted on annual crops such as maize, wheat and cotton [24], and perennial crops including horticultural crops and lucerne. Apart from lucerne, there have been few studies evaluating the long-term effects of applying deficit irrigation to forage/pasture species.

For white clover, extending the irrigation interval beyond E-R of $40 \mathrm{~mm}$, was found to reduce dry matter production by $30 \%$ but only reduced water use by $10 \%$, resulting in an overall decline in irrigation WP [33]. Likewise, for red clover, dry matter production was reduced when the irrigation interval was extended beyond E-R of $80 \mathrm{~mm}$ [33]. However, this study did not evaluate the long-term effects of restricted irrigation on these species nor how these species recovered from the applied drought conditions. For perennial ryegrass irrigated at 33\% of the requirement for optimal soil moisture, dry matter yield was reduced by up to $78 \%$ compared to full irrigation with reductions in leaf dry matter, soluble carbohydrate reserves and even the death of immature tillers [65]. Fu et al. [78,79] concluded that the levels of deficit irrigation required to maintain the turf quality of tall fescue generally ranged from $60 \%$ to $80 \%$ of actual evapotranspiration. However, no such recommendations are available for dairy forages for either dry matter production or nutritive characteristics.

Most researchers evaluating the effects of deficit irrigation on lucerne have reported that deficit irrigation significantly reduces dry matter production [54,80-82]. In an experiment conducted over five years in northern Victoria and involving eight different flood/border check irrigation strategies, lucerne dry matter production was directly related to total water use, however lucerne fully recovered once full irrigation recommenced [54]. In the USA, lucerne grown in the summer without irrigation has been found to require up to one growth cycle after irrigation is resumed for dry matter yields to recover [83-85], however this response depends on a range of factors including the local climate, soil type as well as e plant genotype. For example, lucerne grown on a sandy soil in Arizona, USA did not recover from midsummer deficit irrigation because of the severity of the stress imposed [82]. Similar findings have been reported with perennial ryegrass/white clover pastures in the temperate cooler environment of southwest Victoria [86] where, a 10- or 20-day delay to the start of irrigation in spring resulted in a 35-day delay (once irrigation commenced) for pasture growth rates to reach a level comparable to that of a well-watered pasture. Thus, the effect of deficit irrigation on plant growth is dependent on the environment, irrigation management or method (e.g., border check, pivot, and drip) and plant genotype. Under deficit irrigation, it is important to maintain some soil-water availability so that recovery is possible and to optimise the utilization of subsequent irrigations and rainfall [87].

In a modelling study, Mushtaq and Moghaddasi [88] concluded that it can be difficult to identify the best time to apply a water deficit to minimise the impact on crop yield, quality and stand longevity. These authors suggested that if information such as crop production functions, yield response applications and profit functions are used to determine the optimal or strategic time to employ deficit irrigation, then dry matter reduction can be minimised [88]. Using these methods, these authors found that, under a predicted $30 \%$ reduction in water allocation, economic returns from an irrigation system were maximised by altering the areas of different crops grown-in particular reducing the areas of the low value crops, and slightly modifying the amount of water used per ha on most of the remaining crops [88]. Thus, this strategy could increase overall returns per megalitre of water and offer an effective adaptive response against climate change. In a review of the effects 
of deficit irrigation in western USA, Lindenmayer et al. [89] concluded that deficit irrigation applied over part of the season, may be a better approach than full deficit over an entire season or consecutive seasons. In practice, this means watering only through the months of lower evaporative water demand.

The impact of deficit irrigation on lucerne or pasture stand longevity may be related to the pattern of accumulation of root reserves [90] and to their role in regrowth [24]. In some situations, restricted irrigation practices may seriously affect the density and survival of perennial pasture species and the pasture may require resowing once irrigation is resumed [63,91]. However, in the lucerne study conducted by Rogers et al. [54], that was cut rather than grazed, it was found that there was little decline in plant density and hence persistence in any of the deficit irrigation treatments. In fact, in the final year of the experiment when full irrigation was resumed, the deficit irrigation treatments performed better than the fully watered treatment because of a lower level of weed infestation. Thus, withholding irrigation water over summer may restrict the growth of summer weeds and grasses in some circumstances [82] and could be beneficial as an effective weed control strategy.

The ability to apply deficit irrigation strategies to many forages in the region is limited by the type of irrigation system and the soil type. Under the combination of flood or border-check irrigation systems and the cracking soil types, on which the vast majority of forages in the region are grown, the irrigator has the ability to control when irrigation occurs but has little control over how much irrigation water infiltrates at any given irrigation [92]. In this situation, deficit irrigation is limited to not irrigating for a given time period (such as either a part of or for a full irrigation season) or to increasing the time period between irrigation events. In contrast, with pressurised irrigation systems such as spray or drip-which are rarely used in the region - there is also the ability to reduce the volume of water applied at individual irrigations, thereby increasing the range of deficit irrigation options available, including sustained deficit irrigation (SDI) and regulated deficit irrigation (RDI) [24]. These SDI and RDI methods offer substantial water savings in irrigated annual crops and perennial horticultural crops, respectively [24], but are less applicable for forage crops where the goal is total biomass production.

Another irrigation strategy to improve water productivity is the use of supplemental irrigation [24]. Supplemental irrigation can take a number of forms: in more humid zones, irrigation can be used on perennial species throughout summer, while in more arid zones, small amounts of irrigation water can be used on winter growing annuals. In both cases, a limited volume of irrigation water is used to supplement rainfall and to stabilise yields. Both of these forms of supplemental irrigation are already used to some extent in the dairy industry in the southern Murray Darling Basin, with the summer/autumn spray irrigation of perennial forages undertaken in the more humid and high rainfall valleys of northeast Victoria, and the autumn/spring irrigation of winter growing annual pasture/forages crops undertaken in the riverine plains of southern NSW/northern Victoria [29]. However, there are clearly opportunities to further exploit the concept of supplemental irrigation to improve the biomass returns from the use of irrigation water. When using supplemental irrigation, the concept of marginal water productivity (MWP) (Table 1) should be considered as one way of evaluating the efficiency with which irrigation water is used. This MWP concept has been used in Tasmania, Australia, to compare a range of irrigation treatments using a centre pivot, with MWP declining from 1.9 to $0.3 \mathrm{t} \mathrm{DM} / \mathrm{ML}$ as the marginal amount of water applied increased from nil to $40 \%$ of full irrigation, and from $80 \%$ to full irrigation, respectively [87].

\section{Grazing Management of Water-Stressed Pastures}

The grazing requirements to optimise productivity of perennial pastures under well-watered (rain-fed or full irrigation) conditions are well known [93,94], however, there has been little research on grazing management under deficit irrigation.

Under fully-watered conditions, different pasture species have different tolerances to grazing frequency which are dependent on plant physiology, morphology and sward structure or bud density. In perennial grasses, Fulkerson and Donaghy [94] suggested that if grazing management is based 
on plant-related indicators associated with regrowth, such as leaf-stage, this will maximise pasture production and persistence. These authors recommended that perennial ryegrass should be grazed between the two- and three-leaf stages. Repeated defoliation before the two-leaf stage depleted water soluble carbohydrate reserves and delayed regrowth of leaves and roots, while defoliation after the three-leaf stage resulted in the loss of older leaves through death and decay [94]. Leaf-stage grazing rules based on similar principles have been developed for cocksfoot (Dactylis glomerata L.) $[95,96]$, prairie grass (Bromus willdenowii Kunth.) [97,98], and tall fescue [31].

In perennial legumes, tolerance to intensive grazing is related to growth habit. The prostrate, creeping growth habit of many white clover cultivars enables the plant to tolerate defoliation by grazing since most stolon apices are at, or below, the soil surface and, are thus generally below the grazing height $[48,99]$. In contrast, red clover does not have a stoloniferous growth habit and frequent grazing affects the above-ground growth apices and results in reduced production, persistence and sward life. Thus, herbage accumulation in white clover tends to be greater with more frequent defoliation, whereas red clover is most productive under less frequent defoliation [99]. Frequent cutting of lucerne under an optimal irrigation regime may reduce yield and stand density [100] with later recommendations suggesting that lucerne should be cut when the new shoots at the base of the crown are just below the cutting height [101]. With annual legumes, Stockdale [102] reported that, the highest dry matter production in subterranean clover occurred when defoliation was intensive and infrequent. Persian clover, was relatively insensitive to grazing height during the vegetative stages, unless the grazing interval was relatively short [103,104].

In swards that are experiencing restricted or deficit irrigation conditions, it could be expected that plants would be more vulnerable to the effects of grazing [63]. Therefore, judicial grazing management may be critical to ensure the long-term persistence of the pasture and there may have to be a trade-off between drought resistance/persistence and pasture production [67]. It is believed that overgrazing drought-stressed pastures in summer and autumn is the major cause of poor pasture persistence in southern Australia [105]. Under deficit irrigation, grazing management should be based on species and growth habit and it is important to ensure that water soluble carbohydrate reserves are replenished after a grazing event to maximise persistence [94]. Pasture persistence may be improved by rotational grazing [106,107], leaving greater residual material following grazing, or by resting the pasture and limiting grazing to promote density and persistence [108].

\section{Maintaining Pasture Nutritive Characteristics}

Grazed forages are the main source of energy and nutrients for dairy cows in northern Victoria [29] and their nutritive characteristics are influenced by environmental and phenological factors including season, stage of growth, soil fertility and soil nitrogen status [75]. However, neither dry matter production nor nutritive characteristics of forages can be considered in isolation, and the combination of both, as well as the cow's stage of lactation, and type and level of supplementation, dictates the potential performance of the dairy cows consuming any given diet. In promoting irrigation options (such as deficit irrigation) to manage reduced water allocations, it is important to understand the implications that such options could have on grazed pasture quality. However, we have been unable to find any studies in the literature that have specifically combined the effects of deficit irrigation and grazing management on the nutritive characteristics of grazed forage species.

The nutritive characteristics (dry matter digestibility (DMD), crude protein and neutral detergent fibre) in four forage species (perennial ryegrass, tall fescue, phalaris and lucerne) were reported to be unaffected by the irrigation interval (E-R of $45-50 \mathrm{~mm}$ compared to $80-100 \mathrm{~mm}$ ) [52]. Similar findings were found by Rogers et al. [109] with lucerne in a field study, and by Wilson [110] with three tropical grasses (green panic (Panicum maximum var. Trichoglume), buffel (Cenchrus ciliaris L.) and spear (Austrostipa spp.)) grown in pots. Wilson [110] reported that water-stressed plants had DMD levels similar to, or higher than, those of well-watered plants, and this was attributed to water stress slowing stem development in these grasses. Similar effects of water stress on plant maturity 
and nutritive characteristics have also been found by Vough and Marten [62], Snaydon [111] and Halim et al. [112]. However, when Halim et al. [112] and Carter and Sheaffer [113] accounted for differences in plant maturity, they found no effect of water stress on crude protein concentrations. In contrast, Skinner et al. [49] reported that DMD decreased with drought stress in a range of pasture mixes (including the species chicory, red clover, perennial ryegrass, cocksfoot, Kentucky bluegrass (Poa pratensis L.), and concluded that this was due to tissue age.

Therefore, the grazing management of water-stressed plants needs to ensure their long-term persistence by preventing over-grazing and allowing time for the adequate replenishment of water soluble carbohydrate reserves. In these situations, the use of sacrifice paddocks, or loafing areas, may be required. When water-stressed pastures are grazed, the nutritive characteristics of the forage may be difficult to predict, with water-stress effects ranging from a reduction to an increase in nutritive characteristics. This range of responses appears to be dependent upon a number of factors including the species and the relationship between plant maturity and nutritive characteristics. Specifying grazing management strategies for water-stressed plants will require maintaining a balance between dry matter production, persistence and nutritive characteristics.

\section{Summary and Conclusions}

In this paper, we have reviewed strategies that optimise forage production from limited and variable water inputs in the southern Murray Darling Basin. As water availability reduces, and the cost of irrigation water increases, there is a need to grow forage types with higher WP, however, these forages are often more expensive to grow and usually involve conservation instead of direct grazing. Other factors that need to be considered in the forage selection process are the seasonal distribution of grazed forage supply and feed gaps, the nutritive characteristics of the forage system, and the need to retain the flexibility to respond to changes in the operating environment. Thus, while it is useful to focus on the WP of individual forages, WP is only one of many factors which need to be considered by dairy farmers when choosing which forages to grow and how to allocate their irrigation water.

There are many strategies that may be employed to optimise forage production from water inputs such as selecting appropriate forages, modifying irrigation practices, and managing non-irrigated perennial forages to improve persistence. Selecting appropriate forages may involve using forages that: (i) grow predominantly through the cooler, lower evapotranspiration months (such as winter growing annual pastures); (ii) can survive when not irrigated for lengthy periods, and then respond when irrigated again (such as lucerne); or (iii) have high WP when grown through summer (such as maize). In all of these situations, it is essential to optimise the management of the chosen option. Modifying irrigation practices may lead to making more extensive use of deficit irrigation for lucerne which has a demonstrated ability to survive non-irrigated periods ranging in length from months to several years, without losing plant density, and then responding to subsequent irrigations. Alternatively, shortening the length of the irrigation season for annual pastures and fodder crops will reduce irrigation water use during periods of high evapotranspiration demand and increase the proportion of the total water requirements that comes from rainfall, thereby increasing the irrigation WP of these forages. When managing perennials to improve plant survival over summer, it may be necessary to avoid grazing during water-stress periods and to optimise the length of the non-irrigated period. Often there may need to be a trade-off between dry matter production and persistence, with stock potentially needing to be removed from grazing pasture and located to loafing or sacrifice areas. Furthermore, forage nutritive characteristics may be hard to predict during these water-stressed periods, with changes in quality raging from a decline to an increase, with the response often depending upon changes in plant maturity. Finally, some forages such as perennial pastures, may remain in the system, despite not meeting any of these criteria, as they may provide a cheaper and easily-managed feed source in years of higher water availability and hence lower cost of water. 
Strategies to optimise forage production from limited and variable water inputs need to be viewed in an economic framework. To date, there have not been detailed economic analyses of many of the decisions required around forage selection or the choice of farming system in areas where irrigation water is limited. Prior economic analysis that is available has often been undertaken in a context which is not always relevant to the current environment. Thus, in the future, it is vital that sensitivity analyses of many of the key management options (in terms of costs, prices and production responses) are undertaken. In addition, because of year-to-year variations in environmental and economic conditions, there is a need to maintain flexibility in the feedbase as the ideal forage mix will not be the same every year-and this flexibility is likely to be limited in farm systems that contain large proportions of perennial pastures. Other research gaps are: the management of perennial ryegrass, or tall fescue-based pastures, during periods of summer water-stress and how to achieve a suitable compromise between production and persistence; the management and production of other temperate species; and the role and management of tropical species including legumes if the climate warms as predicted. In all of these situations, it is vital that nutritive characteristics are considered in addition to forage production and WP, although any impacts of nutritive characteristics on animal performance are likely to be small relative to changes in dry matter availability.

In conclusion, the on-farm feed production systems in the southern Murray Darling Basin, based primarily on annual and perennial pastures, have changed substantially over the last two decades in response to reduced water availability as well as on-farm changes in herd sizes, per cow production and supplement use which have reduced the proportion of grazed pasture in the cows' diet. The need for, but not necessarily the direction of, change is likely to continue into the future as dairy farming systems continue to adapt to ongoing water availability issues and advances in technology and management practices.

Acknowledgments: This review was financially supported by Dairy Australia and the Victorian Department of Economic Development, Jobs, Transport and Resources. We thank Joe Jacobs, Bill Wales, Des Whitfield, Yvett Williams and three anonymous reviewers for providing valuable comments to the manuscript.

Author Contributions: Mary-Jane Rogers initiated this review; and Mary-Jane Rogers, Alister Lawson and Kevin Kelly co-wrote this paper.

Conflicts of Interest: The authors declare no conflict of interest.

\section{References}

1. Australian Bureau of Statistics. 4618.0-Water Use on Australian Farms, 2015-2016. Available online: http:/ /www.abs.gov.au/AUSSTATS/abs@.nsf/mf/4618.0 (accessed on 24 September 2017).

2. Ashton, D.; Gomboso, J. Dairy Farms in the Murray-Darling Basin. Available online: http://www.agriculture. gov.au/abares/research-topics/surveys/irrigation/dairy\#dairy-production-in-the-murraydarling-basin (accessed on 5 October 2017).

3. Australian Government-Murray Darling Basin Authority. Murray-Darling Basin Boundary Map. Available online: https:/ / www.mdba.gov.au/publications/products/murray $\%$ E2\% $80 \% 93$ darling-basin-boundarymap (accessed on 20 September 2017).

4. Australian Government. Bureau of Meteorology Climate Statistics for Australian Locations. Available online: http://www.bom.gov.au/climate/averages/tables/cw_081049.shtml (accessed on 20 September 2017). (In Tatura)

5. Stace, H.C.T.; Hubble, G.D.; Brewer, R.; Northcote, K.H.; Sleeman, J.R.; Mulchy, M.J.; Hallsworth, E.G. A Handbook of Australian Soils; Rellim Technical Publications: Adelaide, Australia, 1968.

6. Isbell, R.F. The Australian Soil Classification; CSIRO Publishing: Collingwood, Australia, 1996; ISBN 0-64305-813-3.

7. Australian Government. Bureau of Meteorology Climate Glossary. Available online: http://www.bom.gov. $\mathrm{au} /$ climate/glossary/drought.shtml (accessed on 28 November 2017).

8. Australian Government. Water Act 2007. Available online: https://www.legislation.gov.au/Series/ C2007A00137 (accessed on 9 October 2017). 
9. CSIRO; Bureau of Meteorology. Climate Change in Australia Information for Australia's Natural Resource Management Regions; Technical Report; CSIRO Publishing: Melbourne, Australia, 2015; ISBN 9781921232947. Available online: https://www.climatechangeinaustralia.gov.au/media/ccia/2.1.6/cms_page_media/168/ CCIA_2015_NRM_TechnicalReport_WEB.pdf (accessed on 10 September 2017).

10. Victorian Government-Department of Sustainability and Environment. Northern Region Sustainable Water Strategy; Department of Sustainability and Environment: Melbourne, Australia, 2009; p. 222, ISBN (Print) 978-1-7242-126-1 or (Online) 878-1-74242-127-8.

11. Greenwood, K.L.; Lawson, A.R.; Kelly, K.B. The water balance of irrigated forages in northern Victoria, Australia. Agric. Water Manag. 2009, 96, 847-858. [CrossRef]

12. Neal, J.S.; Fulkerson, W.J.; Lawrie, R.; Barchia, I.M. Difference in yield and persistence among perennial forages used by the dairy industry under optimum and deficit irrigation. Crop Pasture Sci. 2009, 60, 1071-1087. [CrossRef]

13. Doyle, P.T.; Kelly, K.B. The Victorian Dairy Industry-Improving Performance. In Agronomy, Growing a Greener Future, Proceedings of the 9th Australian Agronomy Conference, Charles Sturt University, Wagga Wagga, Australia, 20-23 July 1998; Michalk, D.L., Pratley, J.E., Eds.; Australian Society of Agronomy Inc.: New South Wales, Australia, 1998. Available online: http:/ / www.regional.org.au/au/asa/1998/plenary/quality/doyle.htm\# TopOfPage (accessed on 1 October 2017).

14. Bethune, M.; Armstrong, D. Overview of the irrigated dairy industry in Australia. Aust. J. Exp. Agric. 2004, 44, 127-129. [CrossRef]

15. Bethune, M. Towards effective control of deep drainage under border-check irrigated pasture in the Murray-Darling Basin: A review. Aust. J. Agric. Res. 2004, 55, 485-494. [CrossRef]

16. Armstrong, D.; Knee, J.; Doyle, P.; Pritchard, K.; Gyles, O. A Survey of Water-Use Efficiency on Irrigated Dairy Farms in Northern Victoria and Southern New South Wales; Department of Natural Resources and Environment, Institute of Sustainable Irrigated Agriculture: Victoria, Australia, 1998; ISBN 0-7311-4238-1.

17. Lawson, A.; Kelly, K.; Rogers, M. Modelling water-use of irrigated forage systems in northern Victoria. In Capturing Opportunities and Overcoming Obstacles in Australian Agronomy, Proceedings of the 16th Australian Agronomy Conference, Armidale, Australia, 14-18 October 2012; Yunusa, I., Ed.; Australian Society of Agronomy Inc.: New South Wales, Australia, 2012. Available online: http:/ /www.regional.org.au/au/asa/2012/soilwater-management/7941_lawsonar.htm\#TopOfPage (accessed on 1 October 2017).

18. Stockdale, C.R. Factors affecting the productivity of irrigated annual pastures. 2. Defoliation by dairy cows. Aust. J. Exp. Agric. 1986, 26, 305-313. [CrossRef]

19. Greenwood, K.L.; Mundy, G.N.; Kelly, K.B. On-farm measurement of the water use and productivity of maize. Aust. J. Exp. Agric. 2008, 48, 274-284. [CrossRef]

20. Armstrong, D.P.; Knee, J.E.; Doyle, P.T.; Pritchard, K.E.; Gyles, O. Water-use efficiency on irrigated dairy farms in northern Victoria and southern New South Wales. Aust. J. Exp. Agric. 2000, 40, 643-653. [CrossRef]

21. Linehan, C.J.; Armstrong, D.P.; Doyle, P.T.; Johnson, F. A survey of water use efficiency on irrigated dairy farms in northern Victoria. Aus. J. Exp. Agric. 2004, 44, 131-136. [CrossRef]

22. Armstrong, D.P. Water use efficiency and profitability on an irrigated dairy farm in northern Victoria. Aust. J. Exp. Agric. 2004, 44, 137-144. [CrossRef]

23. Lawson, A.R.; Greenwood, K.L.; Kelly, K.B. Irrigation water productivity of winter-growing annuals is higher than perennial forages in northern Victoria. Crop Pasture Sci. 2009, 60, 407-419. [CrossRef]

24. Fereres, E.; Soriano, M.A. Deficit irrigation for reducing agricultural water use. J. Exp. Bot. 2007, 58, 147-159. [CrossRef] [PubMed]

25. Martin, F.M. Simulation of Pasture Water Relationships and Pasture Growth by a Mathematical Model. Master's Thesis, La Trobe University, Melbourne, Australia, 1978.

26. Allen, R.G.; Pereira, L.S.; Raes, D.; Smith, M. Crop Evapotranspiration: Guidelines for Computing Crop Water Requirements; FAO Irrigation and Drainage Paper No. 56; Food and Agriculture Organization of the United Nations (FAO): Rome, Italy, 1998; ISBN 92-5-104219-5.

27. Christen, E.W.; Jayawardane, N. Measuring water use efficiency and water use productivity. Appendix 4. In The Irrigation Industry in the Murray and Murrumbidgee Basins; CRC for Irrigation Futures Technical Report No. 03/05; Meyer, W., Ed.; CRC for Irrigation Futures: Toowoomba, Australia, 2005; pp. 129-132.

28. Resource Manager-Northern Victoria. Historic Allocation Data. Available online: http://nvrm.net.au/ resources-and-data/historical-allocation-data (accessed on 28 September 2017). 
29. Doyle, P.T.; Stockdale, C.R.; Lawson, A.R.; Cohen, D.C. Pastures for Dairy Production in Victoria, 2nd ed.; Department of Natural Resources and Environment: Kyabram, Australia, 2000; p. 73, ISBN 0-7347-2014-9.

30. Fales, S.L.; Laidlaw, A.S.; Lambert, M.G. Cool-season grass ecosystems. In Cool-Season Forage Grasses; Moser, L.E., Ed.; American Society of Agronomy, Crop Science Society of America and Soil Science of America: Madison, WI, USA, 1996; pp. 267-296.

31. Lawson, A.R.; Kelly, K.B.; Rogers, M.E. Grazing management of dairy pastures based on tall fescue in southern Australia. Crop Pasture Sci. 2017. [CrossRef]

32. Stockdale, C.R. Irrigated pasture productivity and its variability in the Shepparton Region of northern Victoria. Aust. J. Exp. Agric. Anim. Husb. 1983, 23, 131-139. [CrossRef]

33. Kelly, K.B.; Stockdale, C.R.; Mason, W.K. The productivity of irrigated legumes in northern Victoria. 1. Effect of irrigation interval. Aust. J. Exp. Agric. 2005, 45, 1567-1576. [CrossRef]

34. Myers, L.F.; Squires, V.R. Time of first autumn irrigation and the yield and animal production of a subterranean clover-annual ryegrass pasture. Aust. J. Exp. Agric. Anim. Husb. 1970, 10, $279-285$. [CrossRef]

35. Kelly, K.B.; Mason, W.K. Effects of irrigation timing on seedling establishment and productivity of subterranean clover pastures. Aust. J. Exp. Agric. 1987, 27, 545-549. [CrossRef]

36. Kelly, K.B.; Mason, W.K. Evaluation and productivity of some annual Trifolium spp. under irrigation. Aust. J. Exp. Agric. 1986, 26, 79-85. [CrossRef]

37. Rogers, M.E.; Noble, C.L. The Effect of $\mathrm{NaCl}$ on the Establishment and Growth of Balansa Clover (Trifolium michelianum Savi Var. balansae Boiss.). Aust. J. Agric. Res. 1991, 42, 847-857. [CrossRef]

38. Pritchard, K.E.; Small, D.R. Soil and water management for irrigated crops on a red-brown earth soil. In Looking Back-Planning Ahead, Proceedings of the 6th Australian Agronomy Conference, Armidal, Australia, 10-14 February 1992; Armidale, N.S.W., Hutchinson, K.J., Vickery, P.J., Eds.; Australian Society of Agronomy Inc.: New South Wales, Australia, 1992. Available online: http://www.regional.org.au/au/asa/1992/ concurrent/cropping-systems/p-06.htm\#TopOfPage (accessed on 4 October 2017).

39. Pritchard, K.E. Yield and quality of irrigated summer fodder crops in northern Victoria. Aust. J. Exp. Agric. 1987, 27, 817-823. [CrossRef]

40. Shahidi, R.; Yoshida, J.; Cougnan, M.; Reheul, D.; Van Labeke, M.-C. Morpho-physiological responses to dehydration stress of perennial ryegrass and tall fescue genotypes. Funct. Plant Biol. 2017, 44, 612-623. [CrossRef]

41. Nie, Z.; Norton, M.R. Stress tolerance and persistence of perennial grasses: The role of the summer dormancy trait in temperate Australia. Crop Sci. 2009, 49, 2405-2411. [CrossRef]

42. Neal, J.S.; Murphy, S.R.; Harden, S.; Fulkerson, W.J. Differences in soil water content between perennial and annual forages and crops grown under deficit irrigation and used by the dairy industry. Field Crops Res. 2012, 137, 148-162. [CrossRef]

43. Frame, J.; Charlton, J.F.L.; Laidlaw, A.S. Temperate Forage Legumes; CAB International: Wallingford, UK, 1998; Volume 131, ISBN 0-85199-214-5.

44. Blaikie, S.J.; Martin, F.M.; Mason, W.K.; Connor, D.J. Effects of soil water supply and temperature on the photosynthesis of white clover and paspalum in irrigated pastures. Aust. J. Exp. Agric. 1988, 28, 321-326. [CrossRef]

45. Frame, J.; Newbould, P. Agronomy of white clover. Adv. Agron. 1986, 40, 1-88.

46. Rogers, M.E.; Noble, C.L.; Nicolas, M.E.; Halloran, G.M. Leaf, stolon and root growth of white clover (Trifolium repens L.) in response to irrigation with saline water. Irrig. Sci. 1994, 15, 183-194. [CrossRef]

47. Neal, J.S.; Fulkerson, W.J.; Sutton, B.G. Differences in water-use efficiency among perennial forages used by the dairy industry under optimum and deficit irrigation. Irrig. Sci. 2011, 29, 213-232. [CrossRef]

48. Forde, M.B.; Hay, M.J.M.; Brock, J.L. Development and growth characteristics of temperate perennial legumes. In Persistence of Forage Legumes; Marten, G.C., Matches, A.G., Barnes, R.F., Brougham, R.W., Clements, R.J., Sheath, G.W., Eds.; American Society of Agronomy: Madison, WI, USA, 1989; pp. 91-109, ISBN 978-0-89118-245-0.

49. Skinner, R.H.; Gustine, D.L.; Sanderson, M.A. Growth, water relations and nutritive value of pasture species mixtures under moisture stress. Crop Sci. 2004, 44, 1361-1369. [CrossRef]

50. Bouton, J.H. Breeding lucerne for persistence. Crop Pasture Sci. 2012, 63, 95-106. [CrossRef] 
51. Pembleton, K.G.; Rawnsley, R.P.; Donaghy, D.J. Yield and water-use efficiency of contrasting lucerne genotypes in a cool temperate environment. Crop Pasture Sci. 2011, 62, 610-623. [CrossRef]

52. Greenwood, K.L.; Dellow, K.E.; Mundy, G.N.; Kelly, K.B.; Austin, S.M. Improved soil and irrigation management for forage production 2. Forage yield and nutritive characteristics. Aust. J. Exp. Agric. 2006, 46, 319-326. [CrossRef]

53. Heard, J.W.; Porker, M.J.; Armstrong, D.P.; Finger, L.; Ho, C.K.M.; Wales, W.J.; Malcolm, B. The economics of subsurface drip irrigation on perennial pastures and fodder production in Australia. Agric. Water Manag. 2012, 111, 68-78. [CrossRef]

54. Rogers, M.E.; Lawson, A.R.; Kelly, K.B. Lucerne yield, water productivity and persistence under variable and restricted irrigation strategies. Crop Pasture Sci. 2016, 67, 563-573. [CrossRef]

55. Peterson, P.R.; Sheaffer, C.C.; Hall, M.H. Drought effects on perennial forage legume yield and quality. Agron. J. 1992, 84, 774-779. [CrossRef]

56. Brown, P.W.; Tanner, C.B. Alfalfa stem and leaf growth during water stress. Agron. J. 1983, 75, $799-805$. [CrossRef]

57. Aparicio-Tejo, P.M.; Sanchez-Diaz, M.F.; Pena, J.I. Nitrogen-fixation, stomatal response and transpiration in Medicago sativa, Trifolium repens and Trifolium subterraneum under water-stress and recovery. Physiol. Plant 1980, 48, 1-4. [CrossRef]

58. Hume, D.E.; Lyons, T.B.; Hay, R.J.M. Evaluation of grasslands Puna chicory (Cichorium intybus L.) in various grass mixtures under sheep grazing. N. Z. J. Agric. Res. 1995, 38, 317-328. [CrossRef]

59. Jiang, Y.; Cui, Y.; Pei, Z.; Liu, H.; Sun, S. Growth response and gene expression to deficit irrigation and recovery of two perennial ryegrass accessions contrasting in drought tolerance. HortScience 2016, 51, 921-926.

60. Mason, W.; Kelly, K.; Blaikie, S.; Stockdale, R. New directions for irrigated pastures. In Responding to Change, Proceedings of the 4th Australian Agronomy Conference, Melbourne, Australia 24-27 August 1987; Reeves, T.G., Ed.; Australian Society of Agronomy Inc.: Victoria, Australia, 1987; pp. 100-117. Available online: http:/ / www.regional.org.au/au/asa/1987/reviews/p-04.htm\#TopOfPage (accessed on 5 October 2017).

61. Blaikie, S.J.; Martin, F.M. Limits to the productivity of irrigated pastures in south-east Australia. In Temperate Pastures: Their Production, Use and Management; Wheeler, J.L., Pearson, C.J., Robards, G.E., Eds.; CSIRO Publishing: Melbourne, Australia, 1987; pp. 119-122, ISBN 0-6430-4773-5.

62. Vough, L.R.; Marten, G.C. Influence of soil moisture and ambient temperature on yield and quality of alfalfa forage. Agron. J. 1971, 63, 40-42. [CrossRef]

63. Waller, R.A.; Sale, P.W.G. Persistence and productivity of perennial ryegrass in sheep pastures in south-western Victoria: a review. Aust. J. Exp. Agric. 2001, 41, 117-144. [CrossRef]

64. Yu, X.; Bai, G.; Liu, S.; Luo, N.; Wang, Y.; Richmond, D.S.; Pijut, P.M.; Jackson, S.A.; Yu, J.; Jiang, Y. Association of candidate genes with drought tolerance traits in diverse perennial ryegrass accessions. J. Exp. Bot. 2013, 64, 1537-1551. [CrossRef] [PubMed]

65. Hatier, J.-H.B.; Faville, M.J.; Hickey, M.J.; Koolaard, J.P.; Schmidt, B.-L.C; Jones, C.S. Plant vigour at establishment and following defoliation are both associated with responses to drought in perennial ryegrass (Lolium perenne L.). J. Exp. Bot. 2014, 65, 5823-5834. [CrossRef] [PubMed]

66. Matthew, C.; van der Linden, A.; Hussain, S.; Easton, H.S.; Hatier, J.H.B.; Horne, D.J. Which way forward in the quest for drought tolerance in perennial ryegrass? Proc. N. Z. Grassl. Assoc. 2012, 74, 195-200.

67. Turner, L.R.; Holloway-Phillips, M.M.; Rawnsley, R.P.; Donaghy, D.J.; Pembleton, K.G. The morphological and physiological responses of perennial ryegrass (Lolium perenne L.), cocksfoot (Dactylis glomerata L.) and tall fescue (Festuca arundinacea Schreb; syn. Schedonorus phoenix Scop.) to variable water availability. Grass Forage Sci. 2012, 67, 507-518. [CrossRef]

68. Norton, M.R.; Volaire, F.; Lelièvre, F. Summer dormancy in Festuca arundinacea Schreb; the influence of season of sowing and a simulated mid-summer storm on two contrasting cultivars. Aust. J. Agric. Res. 2006, 57, 1267-1277. [CrossRef]

69. Pirnajmedin, F.; Majidi, M.M.; Gheysari, M. Root and physiological characteristics associated with drought tolerance in Iranian tall fescue. Euphytica 2015, 202, 141-155. [CrossRef]

70. Norton, M.R.; Malinowski, D.P.; Volaire, F. Plant drought survival under climate change and strategies to improve perennial grasses. A review. Agron. Sustain. Dev. 2016, 36, 1-15. [CrossRef]

71. Volaire, F.; Norton, M. Summer dormancy in perennial temperate grasses. Ann. Bot. 2006, 98, 927-933. [CrossRef] [PubMed] 
72. Volaire, F.; Barkaoui, K.; Norton, M. Designing resilient and sustainable grasslands for a drier future: Adaptive strategies, functional traits and biotic interactions. Eur. J. Agron. 2014, 52, 81-89. [CrossRef]

73. Hoffman, A.A.; Parsons, P.A. Evolutionary Genetics and Environmental Stress; Oxford University Press: Oxford, UK, 1993; ISBN 978-0-19854-081-6.

74. Liu, S.; Jiang, Y. Identification of differentially expressed genes under drought stress in perennial ryegrass. Physiol. Plant. 2010, 139, 375-387. [CrossRef] [PubMed]

75. Fulkerson, W.J.; Neal, J.S.; Clark, C.F.; Horadagoda, A.; Nandra, K.S.; Barchia, I. Nutritive value of forage species grown in the warm temperate climate for dairy cows: Grass and legumes. Livest. Sci. 2007, 107, 253-264. [CrossRef]

76. Lynch, J.P.; O'Kiely, P.O.; Doyle, E.M. Yield, nutritive value and ensilage characteristics of whole-crop maize, and of the separated cob and stover components-Nitrogen, harvest dates and cultivar effects. J. Agric. Sci. 2013, 151, 347-367. [CrossRef]

77. Ho, C.K.M.; Armstrong, D.P.; Malcolm, L.R.; Doyle, P.T. Evaluating options for irrigated dairy farm systems in northern Victoria when irrigation water availability decreases and prices increases. Aust. J. Exp. Agric. 2007, 47, 1085-1094. [CrossRef]

78. Fu, J.; Fry, J.; Huang, B. Minimum Water Requirements of Four Turfgrasses in the Transition Zone. HortScience 2004, 39, 1740-1744.

79. Fu, J.; Fry, J.; Huang, B. Tall Fescue Rooting as Affected by Deficit Irrigation. HortScience 2007, 42, 688-691.

80. Bauder, J.W.; Bauer, A.; Ramirez, J.M.; Cassel, D.K. Alfalfa water use and production on dryland and irrigated sandy loam. Agron. J. 1978, 70, 95-99. [CrossRef]

81. Metochis, C.; Orphanos, P.I. Alfalfa yield and water use when forced into dormancy by withholding water during the summer. Agron. J. 1981, 73, 1048-1050. [CrossRef]

82. Ottman, M.J.; Tickes, B.R.; Roth, R.L. Alfalfa yield and stand response to irrigation termination in an arid environment. Agron. J. 1996, 88, 44-48. [CrossRef]

83. Frate, C.A.; Roberts, B.A.; Marble, V.L. Imposed drought stress has no long-term effect on established alfalfa. Calif. Agric. 1991, 45, 33-36.

84. Guitjens, J.C. Alfalfa irrigation during drought. J. Irrig. Drain. Eng. 1993, 119, 1092-1098. [CrossRef]

85. Hanson, B.; Putnam, D.; Snyder, R. Deficit irrigation of alfalfa as a strategy for providing water for water-short areas. Agric. Water Manag. 2007, 93, 73-80. [CrossRef]

86. Ward, G.; Burch, S.; Jacobs, J.; Ryan, M.; McKenzie, F.; Rigby, S. Effects of sub-optimal irrigation practices on dairy pastures in south west Victoria. In Agronomy-Growing a Greener Future, Proceedings of the 9th Australian Agronomy Conference, Wagga Wagga, Australia, 20-23 July 1998; Michalk, D.L., Pratley, J.E., Eds.; Australian Society of Agronomy Inc.: Wagga Wagga, Australia, 1998. Available online: http:/ /www.regional.org.au/ au/asa/1988/2/060ward.htm\#TopOfPage (accessed on 23 October 2017).

87. Rawnsley, R.P.; Cullen, B.R.; Turner, L.R.; Donaghy, D.J.; Freeman, M.; Christie, K.M. Potential of deficit irrigation to increase marginal irrigation response of perennial ryegrass (Lolium perenne L.) on Tasmanian dairy farms. Crop Pasture Sci. 2009, 60, 1156-1164. [CrossRef]

88. Mushtaq, S.; Moghaddasi, M. Evaluating the potentials of deficit irrigation as an adaptive response to climate change and environmental demand. Environ. Sci. Policy 2011, 14, 1139-1150. [CrossRef]

89. Lindenmayer, R.B.; Hansen, N.C.; Brummer, J.; Pritchett, J.G. Deficit irrigation of alfalfa for water-savings in the Great Plains and Intermountain West: A review and analysis of the Literature. Agron. J. 2011, 103, 45-50. [CrossRef]

90. Rapoport, H.F.; Travis, R.L. Alfalfa root growth, cambial activity, and carbohydrate dynamics during the regrowth cycle. Crop Sci. 1984, 24, 899-903. [CrossRef]

91. Rogers, M.E.; Lawson, A.R.; Kelly, K.B. Strategies to enhance perennial ryegrass persistence over summer. In Doing More with Less, Proceedings of the 18th Australian Agronomy Conference, Ballarat, Australia, 24-28 September 2017; O'Leary, G.J., Armstrong, R.D., Hafner, L., Eds.; Australian Society of Agronomy Inc.: Australia, 2017; Available online: http://www.agronomyaustraliaproceedings.org/ (accessed on 23 October 2017).

92. Wood, M.L.; Finger, L. Influence of irrigation method on water use and production of perennial pastures in northern Victoria. Aust. J. Exp. Agric. 2006, 46, 1605-1614. [CrossRef]

93. Parsons, A.J.; Chapman, D.F. The principles of pasture growth and utilization. In Grass: Its Production and Utilization; Hopkins, A., Ed.; Blackwell Science Ltd.: Oxford, UK, 2000; pp. 31-89, ISBN 978-0-63205-017-8. 
94. Fulkerson, W.J.; Donaghy, D.J. Plant-soluble carbohydrate reserves and senescence-key criteria for developing an effective grazing management system for ryegrass-based pastures. A review. Aust. J. Exp. Agric. 2001, 41, 261-275. [CrossRef]

95. Rawnsley, R.P.; Donaghy, D.J.; Fulkerson, W.J.; Lane, P.A. Changes in the physiology and feed quality of cocksfoot (Dactylis glomerata L.) during regrowth. Grass Forage Sci. 2002, 57, 203-211. [CrossRef]

96. Turner, L.R.; Donaghy, D.J.; Lane, P.A.; Rawnsley, R.P. Effect of defoliation management, based on leaf stage, on perennial ryegrass (Lolium perenne L.), prairie grass (Bromus willdenowii Kunth.) and cocksfoot (Dactylis glomerata L.) under dryland conditions. 1. Regrowth, tillering and water-soluble carbohydrate concentration. Grass Forage Sci. 2006, 61, 164-174.

97. Fulkerson, W.J.; Fennell, J.F.M.; Slack, K. Production and forage quality of prairie grass (Bromus willdenowii) in comparison to perennial ryegrass (Lolium perenne) and tall fescue (Festuca arundinacea) in subtropical dairy pastures. Aust. J. Exp. Agric. 2000, 40, 1059-1068. [CrossRef]

98. Turner, L.R.; Donaghy, D.J.; Lane, P.A.; Rawnsley, R.P. Changes in the physiology and feed quality of prairie grass during regrowth. Agron. J. 2006, 98, 1326-1332. [CrossRef]

99. Kelly, K.B.; Stockdale, C.R.; Mason, W.K. The productivity of irrigated legumes in northern Victoria. 2. Effect of grazing management. Aus. J. Exp. Agric. 2005, 45, 1577-1585. [CrossRef]

100. Slarke, R.H.; Mason, W.K. Effect of growth stage at cutting on yield and quality of Lucerne cultivars from different dormancy groups in northern Victoria. Aust. J. Exp. Agric. 1987, 27, 55-58. [CrossRef]

101. Bouchier, J. Cutting lucerne for hay. In DNRE Agriculture Notes AG0231; DNRE: Melbourne, Australia, 1998.

102. Stockdale, C.R. The productivity of irrigated legumes in northern Victoria. 3. Frequency and intensity of defoliation of subterranean clover. Aust. J. Exp. Agric. 2005, 45, 1587-1594. [CrossRef]

103. Stockdale, C.R. Effects of frequency and height of defoliation on the production of a Persian clover-annual ryegrass sward. Aust. J. Exp. Agric. 1992, 32, 339-344. [CrossRef]

104. Stockdale, C.R. Effects of defoliation management on the productivity of an irrigated Persian clover sward. Aust. J. Exp. Agric. 1994, 34, 205-211. [CrossRef]

105. Beattie, A.S. Grazing for pasture management in the high-rainfall, perennial pasture zone of Australia. In Pasture Management: Technology for the 21st Century; Kemp, D.R., Michalk, D.L., Eds.; CSIRO Publishing: Melbourne, Australia, 1994; pp. 62-70.

106. Saul, G.; Waller, L.; Warn, L.; Hill, R. Grazing management for sheep pastures in Victoria: Update on current research results. In Proceedings of the 39th Annual Conference of the Grassland Society of Victoria, Mornington, Australia, 17-19 June 1998; pp. 87-95.

107. Barker, D.J.; Anderson, C.B.; Dymock, N. “Grassland Wana” cocksfoot persistence and autumn/winter production in hill country, under contrasting management and micro topographies. N. Z. J. Agric. Res. 1991, 34, 25-30. [CrossRef]

108. Nie, Z.N.; Mackay, D.J.; Valentine, I.; Hodgson, J. Changes in plant population density, composition and sward structure of a hill pasture during a pasture fallow. Grass Forage Sci. 1997, 52, 190-198. [CrossRef]

109. Rogers, M.E.; Lawson, A.R.; Chandra, S.; Kelly, K.B. Limited application of irrigation water does not affect the nutritive characteristics of Lucerne. Anim. Prod. Sci. 2014, 54, 1635-1640. [CrossRef]

110. Wilson, J.R. Effects of Water Stress on in vitro Dry Matter Digestibility and Chemical Composition of Herbage of Tropical Species. Aust. J. Agric. Res. 1983, 34, 377-390. [CrossRef]

111. Snaydon, R.W. The effect of total water supply, and frequency of application, upon Lucerne. II. Chemical composition. Aust. J. Agric. Sci. 1972, 23, 253-256. [CrossRef]

112. Halim, R.A.; Buxton, D.R.; Hattendorf, M.J.; Carlson, R.E. Water-stress effects on alfalfa quality after adjustment for maturity differences. Agron. J. 1989, 81, 189-194. [CrossRef]

113. Carter, P.R.; Sheaffer, C.C. Alfalfa Response to Soil Water Deficits. 1. Growth, Forage Quality, Yield, Water Use, and Water Use Efficiency. Crop Sci. 1983, 23, 669-675. [CrossRef]

(C) 2017 by the authors. Licensee MDPI, Basel, Switzerland. This article is an open access article distributed under the terms and conditions of the Creative Commons Attribution (CC BY) license (http:/ / creativecommons.org/licenses/by/4.0/). 